\title{
Spatial variation in structure of an intertidal fish assemblage reflects daily settlement patterns
}

\author{
Amy F. Ritter*, Rikke K. Preisler \\ Department of Ecology and Evolutionary Biology, University of California, Santa Cruz, 1156 High Street, Santa Cruz, \\ California 95064, USA
}

\begin{abstract}
Patterns of population replenishment for marine organisms with dispersive larvae can be influenced by processes acting prior to, during, or subsequent to larval settlement into adult populations. We investigated the relative importance of settlement and post-settlement processes in determining the population structure of an assemblage of rocky intertidal fishes (the sculpins Clinocottus globiceps, C. recalvus and Oligocottus snyderi) in central California. We monitored the daily arrival of new settlers and the monthly density of other life history stages, comprising recruits, juveniles, and adults, during the peak of the sculpin recruitment season in 2002 and 2003 at 2 intertidal sites. We also used mark-recapture methods in 2003 to estimate differences in post-settlement mortality, and report the results of laboratory studies which indicate that these methods do not bias mortality estimates. The daily settlement and monthly abundance surveys revealed that for both years the differences in species densities between sites were largely consistent across all life history stages, even though the stages reflected different cohorts. There was also no evidence that differences in rates of post-settlement survivorship among species altered the original assemblage structure determined at settlement. Together, these results indicate that processes acting at or prior to settlement are a major determinant of the local population size and structure of intertidal fishes in the study region. This study suggests that a more complete understanding of the relative influence of settlement versus post-settlement processes requires further examination of processes influencing larval dispersal and delivery and the degree to which local populations of marine organisms are open or closed.
\end{abstract}

KEY WORDS: Settlement - Recruitment - Intertidal zone · Tidepool fishes · Population dynamics · Assemblage structure $\cdot$ Cottidae

\section{INTRODUCTION}

The life history of most marine organisms involves 2 key phases: (1) early life stages (eggs, larvae) that can exist in the pelagic environment for prolonged periods (several days to months), during which time they are subject to long-distance transport by ocean currents on the order of 0 to $100 \mathrm{~s} \mathrm{~km} \mathrm{(Kinlan} \mathrm{\&} \mathrm{Gaines}$ 2003, Shanks et al. 2003); and (2) older, more sedentary life stages (juveniles, adults) that exhibit far more restricted movement ( 0 to $100 \mathrm{~s} \mathrm{~m}$ ) in the benthic environment. This discrepancy in dispersal potential between adults and their offspring can translate into a spatial structure in which local populations and communities are replenished largely by young that are produced elsewhere, thereby decoupling local propagule production and replenishment (Sale 1980, 1991, Gaines \& Roughgarden 1985, Doherty \& Williams 1988, Caley et al. 1996). The replenishment and dynamics of these so-called 'open populations' (sensu Caswell 1978) is influenced by the highly variable delivery of young, their permanent transition to the benthic environment (i.e. settlement), and subsequent survival. Thus, our ability to predict the distribution and dynamics of marine populations, and the communities they constitute, is contingent upon our knowledge of the relative contributions of variability in the supply of young, their settlement into benthic populations, and patterns of mortality that affect the abundance of subsequent life stages. 
Our understanding of the relative contributions of variable larval delivery, settlement and post-settlement survival in determining the distribution and dynamics of local populations (and communities) has been impeded by the difficulty of measuring and distinguishing rates of propagule supply, settlement, and early post-settlement mortality. Estimates of the rate of input of new individuals to a benthic population (referred to as 'recruitment') are typically measured at some arbitrary point subsequent to settlement (Keough \& Downes 1982, Underwood \& Denley 1984, Connell 1985, but see Gaines et al. 1985, Breitburg 1991). Measures of recruitment based on this operational definition, therefore, include only those individuals that survive post-settlement/pre-census periods that vary markedly among studies from hours, to days, to months or more (reviewed by Caley et al. 1996). Rates of postsettlement mortality can be very high soon after settlement, and such high mortality can decouple recruitment estimates from actual rates of settlement (Booth 1991, Forrester 1995, Hixon \& Carr 1997). However, it is rare that researchers have distinguished between, and separately estimated, the relative rates of supply, settlement and recruitment, and the potential bias in recruitment measures introduced by variable or density-dependent post-settlement mortality. In order to minimize any bias or confounding by post-settlement mortality, it is extremely important that recruitment is estimated as close to the settlement phase as possible when trying to determine the relative importance of variable larval supply and how it contributes to the structure and dynamics of benthic populations (Booth 1991, Milicich et al. 1992, Minchinton \& Scheibling 1993).

Few studies have compared the relative importance of settlement versus post-settlement processes in determining the population structure of nearshore marine fishes, and most of these have examined these processes in coral reef fishes (Milicich et al. 1992, Doherty \& Fowler 1994, Caselle 1999, Schmitt \& Holbrook 1999, Wilson \& Osenberg 2002). Only a few studies have compared these processes in temperate reef fishes (Levin 1994, Tupper \& Boutilier 1995, Steele 1997), and to our knowledge none have compared settlement and post-settlement processes in intertidal fishes, despite the large number of studies that have addressed the same questions in intertidal invertebrates (Caffey 1985, Connell 1985, Gaines \& Roughgarden 1985, Raimondi 1990, Menge 2000). Recently, 2 studies have examined how recruitment dynamics affect the population structure of adult intertidal fishes (Pfister 1996, Davis \& Levin 2002), but both studies focused on processes occurring subsequent to recruitment measured on a monthly or seasonal basis, and were therefore unable to assess how settlement and post-settlement processes (occurring prior to the time when recruitment was first measured) affected the patterns of recruitment and subsequent abundance. An examination of the relative importance of settlement and post-settlement processes in intertidal fishes is crucial to gaining an understanding of the relative effects of these processes in structuring intertidal fish populations and assemblages, and would allow comparison of the settlement and recruitment patterns to those found in previous studies of both nearshore fishes and intertidal invertebrates.

The goals of our study were to investigate the relative importance of settlement versus post-settlement processes in determining the population and assemblage structure of tidepool fishes. Specifically, our objectives were to characterize the spatial and temporal patterns of settlement in an assemblage of 3 species of tidepool fishes, determine the spatial and temporal patterns of post-settlement survivorship of each species, and compare these estimates of settlement and post-settlement survivorship to the abundance and composition of the species assemblage across several life history stages. In addition, we used different sampling frequencies of settlement and post-settlement abundance to ascertain their effects on estimates of mortality and to make inferences regarding the relative effects of settlement and post-settlement processes.

\section{MATERIALS AND METHODS}

Study species. Sculpins (family Cottidae) constitute a predominant component of rocky intertidal fish assemblages along the western coast of North America in terms of species number, density and biomass (Yoshiyama et al. 1986). Clinocottus globiceps (the mosshead sculpin), C. recalvus (the bald sculpin), and Oligocottus snyderi (the fluffy sculpin) are 3 of the most abundant intertidal fish species along the coast of central California, USA. Within the rocky intertidal zone, the distributions of these sculpin species vary with tidal height: $O$. snyderi is found typically in the low- to mid-intertidal zone, whereas the distributions of $C$. globiceps and C. recalvus are broader, spanning the low- to high-intertidal zones (Hubbs 1966, Nakamura 1976, Yoshiyama et al. 1986, Martin 1993). At larger biogeographic scales, C. recalvus is common from northern central California to southern California, whereas C. globiceps and O. snyderi are common from British Columbia to central California (Miller \& Lea 1972, Yoshiyama et al. 1986). All 3 species have a protracted reproductive season from November to April (Grossman \& Devlaming 1984). Female sculpins are fertilized internally and lay clutches of eggs that 
remain in the intertidal zone for $\sim 3$ wk (DeMartini 1999). The larvae then spend $\sim 1$ mo in the plankton, before settling into the tidepool habitat (Washington et al. 1984, Blizard 2000). The recruitment season of $C$. globiceps, C. recalvus, and O. snyderi occurs from March through August, peaking in June (Pfister 1996, 1997, Ritter 2005). We focused on these 3 species because they are the dominant constituents of the lowto mid-intertidal fish assemblage in our study area.

Study area and general sampling. We monitored the assemblages of tidepool sculpins at 2 rocky intertidal sites, Almar and Scott Creek, both comprised of Santa Cruz mudstone formation and located in the vicinity of the Monterey Bay approximately $90 \mathrm{~km}$ south of San Francisco along the coast of central California. Almar is located within the northern Monterey Bay, whereas Scott Creek is located approximately $20 \mathrm{~km}$ away, just north of Monterey Bay (Fig. 1). At each site we repeatedly censused a set of 5 tidepools daily and a set of 5 to 7 tidepools monthly (hereafter referred to as 'daily' and 'monthly' tidepools) to determine levels of settlement and recruitment. Relative to Scott Creek, Almar has less overall tidepool habitat available and tends to be at a higher elevation than Scott Creek, although absolute tidal height of tidepools at each site may not be representative of effective tidal height due to differences in the inclination and geographical position of each site (Harley \& Helmuth 2003). Consequently, to ensure that our study tidepools were within the tidal range of each of the 3 focal species (the low- to midintertidal zone), we specifically chose study pools that were located in the mussel zone at each site (A. Ritter pers. obs.). The pools we monitored in the daily settlement surveys were smaller than the pools we monitored in the monthly recruitment surveys. Monitoring smaller pools for the daily surveys facilitated daily sampling even on days when the low-tide period was extremely short, and also minimized the effects of settler interactions with adults (adults are uncommon in small pools). Although pool characteristics did vary somewhat between sites and between pool categories (i.e. those sampled daily versus those sampled monthly), there were no consistent differences between sites that should affect the outcome of our surveys (Table 1). We estimated settlement as the arrival of new individuals into the focal tidepools on a daily basis, and recruitment as the proportion of settlers remaining in the population at monthly intervals (similar to Connell 1985). We attempted to minimize the bias that post-settlement mortality and movement may have had on our estimates of settlement by (1) monitoring these

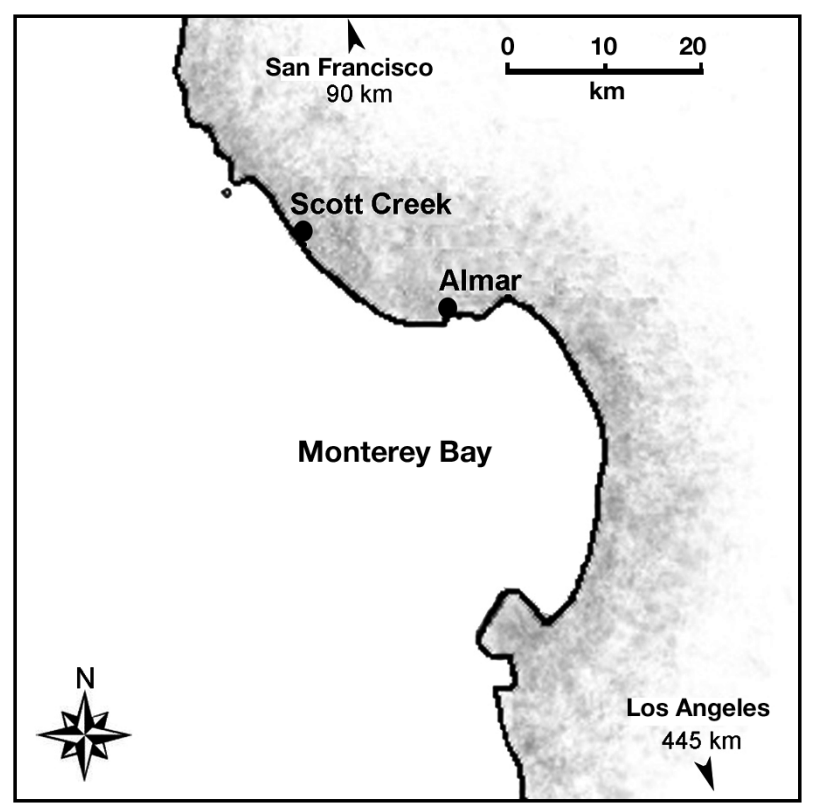

Fig. 1. Locations of study sites (•) in Monterey Bay, central California. The 2 study sites are approximately $20 \mathrm{~km}$ apart

pools as frequently as possible and (2) categorizing recently settled fish as those $\leq 17 \mathrm{~mm}$ in standard length, a size range which includes fish that can have little to no pigmentation (A. Ritter pers. obs.) and most likely includes the size range of recent settlers based on the size ranges of offshore pre-settlement transformation-phase larvae (Ambrose 1996). However, our classification of 'new settlers' may have led to the inclusion of some fishes that settled prior to the previous $24 \mathrm{~h}$ and migrated into the 'daily' pools during the $24 \mathrm{~h}$ period between surveys. Nevertheless, these estimates provide the best available current methodology for estimating settlement rates of tidepool fishes as close to the timing of actual settlement as possible. Fish were sampled by removing most of the water from each pool using gallon-sized (4 l) buckets, and collecting individuals with small dipnets. For all captured fish, we recorded their species identification, size

Table 1. Average ( \pm SD) physical characteristics of tidepools surveyed at Almar and at Scott Creek during daily monthly surveys

\begin{tabular}{|lcccc|}
\hline Study site & $\begin{array}{c}\text { Surface area } \\
\left(\mathrm{cm}^{2}\right)\end{array}$ & $\begin{array}{c}\text { Proportion cover } \\
\text { (algae/surfgrass) }\end{array}$ & $\begin{array}{c}\text { Volume } \\
(\mathrm{l})\end{array}$ & $\begin{array}{c}\text { Tidal height } \\
(\mathrm{m})\end{array}$ \\
\hline Daily & & & & \\
Almar & $1961.5 \pm 644.2$ & $0.847 \pm 0.099$ & $15.02 \pm 7.410$ & $1.325 \pm 0.096$ \\
Scott Creek & $2869.2 \pm 698.7$ & $0.930 \pm 0.028$ & $7.440 \pm 3.680$ & $0.644 \pm 0.025$ \\
Monthly & & & & \\
Almar & $6654.2 \pm 2288.7$ & $0.618 \pm 0.045$ & $120.46 \pm 147.48$ & $1.409 \pm 0.105$ \\
Scott Creek & $6683.3 \pm 2664.1$ & $0.599 \pm 0.372$ & $251.05 \pm 267.40$ & $0.782 \pm 0.148$ \\
& & & & \\
\hline
\end{tabular}


(standard length), source pool, gender (if detectable), and tag (if previously tagged), and then returned the fish to their original pools (except for the settlement surveys in 2002, see next subsection).

Settlement surveys. In June 2002 we monitored settlement bi-daily (every other day) during the first spring low-tide series from 10 June to 19 June 2002 (5 d per site), and daily during the second spring lowtide series from 24 June to 1 July 2002 (8 d per site). At this time of year, the tidal cycle of the eastern Pacific is mixed semidiurnal, whereby a spring low-tide series usually lasts 5 to $9 \mathrm{~d}$, followed by a neap low-tide series of similar duration. Only during the spring low-tide series are the tides low enough to allow sampling of tidepools in the low intertidal zone, and thus our field sampling in this study was restricted to spring low tides. For these 2002 settlement surveys, we removed all collected fish after every sampling day. This facilitated estimation of the number of new fishes that had settled since the previous sampling day, although it precluded estimation of other demographic factors (such as survivorship). Sculpins that we classified as new settlers into tidepools were approximately 13 to $17 \mathrm{~mm}$ in standard length (SL) or less (based on visual observation of degree of pigmentation).

In June 2003 we monitored the daily settlement levels of intertidal sculpins during 2 spring low-tide series, from 30 May to 8 June (10 d per site) for the first low-tide series and from 14 to 20 June for the second low-tide series ( $7 \mathrm{~d}$ per site). For every sampling date, we tagged all untagged fish, and recorded tagged fish as previously tagged; we also recorded other demographic information (size, gender, pool, etc.), and then returned the fish to their original pools. To indicate which individuals had already been captured, we tagged each fish with a small subcutaneous injection of elastomer (Northwest Marine Technology), a colored silicone compound, using a 3/10 ml syringe with a 31 gauge $(0.254 \mathrm{~mm} \varnothing) \times 8 \mathrm{~mm}$ needle. The streaks of colored elastomer are visible through clear portions of skin and scales (see Malone et al. 1999 for a description of the use of elastomer). By tagging and returning sampled fish, we were able to estimate loss rates (loss due to mortality and movement of individuals out of original pools) in addition to the number of new fish that had arrived by each sampling day. Daily settlement levels were determined for each sampling date based on the number of captured fish per pool that were untagged and that were $\leq 17 \mathrm{~mm}$ SL.

To determine whether settlement varied between the 2 sites, among the 3 species and over time, and whether there were any interactions between these factors, we analyzed the between- and within-subject effects for 2002 and for 2003 using univariate repeated-measures ANOVAs; there were not enough degrees of freedom to run multivariate repeatedmeasures ANOVAs since there were more repeated measures than replicated units within treatments. Due to the split-plot design of this study, the repeatedly surveyed pools are the basic experimental subjects in the design and provide the replicated units for comparisons between the 2 study sites, and each of the study pools provides a count for each species at any one time (i.e. each pool is a sub-plot). Consequently, the appropriate analysis-of-variance test for the main effect of site in the between-subjects analysis was to use the mean square (and degrees of freedom) from the term 'pools' nested within 'sites' as the denominator (rather than the residual). The design also involves 2 withinsubjects components with their correspondingly unique residual terms: the within-subjects terms (the first split of the plot because each species was counted in each pool) and the within-sub-subjects terms (the split of the split-plots as a consequence of the repeated measures over time). Because the data from the 2 tide series in June of 2002 were collected at different frequencies, we specified the appropriate metric (i.e. 1 or $2 \mathrm{~d}$ ) for the repeated sampling of these pools in the analysis. We excluded the first sampling day of each tide series at each site from the analysis since these counts did not represent settlement within the past $24 \mathrm{~h}$. For each analysis, the data were $x^{0.5}$-transformed in order to meet the assumptions of the univariate repeated-measures ANOVA, based on visual verification of frequency plots as formal tests of normality and homogeneity are typically too stringent (Quinn \& Keough 2002). The transformation centralized the distribution of non-zero values but was not able to correct for the high frequency of zero values in the data; nevertheless, ANOVA is robust to this type of assumption violation (Quinn \& Keough 2002). Based on observations of cross-correlations between sampling occasions, the data also met the assumption of sphericity for the univariate repeated-measures ANOVA; however, to be conservative we report the Greenhouse-Geisser corrected p-values for each analysis.

Post-settlement survivorship. We used the mark-recapture data from our daily settlement surveys to determine the number of tagged and untagged fishes captured on each sampling date. To estimate daily survivorship and movement rates, we fit these data using the Gauss-Newton estimation method to the following least-squares function: $T_{i}=M \times \Sigma\left(U_{i-1} \times S\right)$, where the 2 parameters with known values were $T_{i}$ (the number of tagged fish recaptured on Day i) and $U_{i-1}$ (the number of untagged fish initially captured and tagged on Day i-1). The 2 parameters that we estimated with this function were $M$, the average daily movement rate, and $S$, the average daily survivorship rate. We ran several iterations of the function until the 
model converged on the best-fitting estimates of $M$ and $S$. We determined that the least-squares function was an appropriate model for estimating the unknown parameters by plotting the expected versus the actual recaptures for each species separately and verifying evenness in the spread of the residuals for all values of expected and observed recaptures.

Monthly surveys. In June, July, and August 2002, and May and June 2003, we monitored the density of intertidal sculpins in a set of 5 to 7 'monthly' survey pools during 1 low-tide day at both Almar and at Scott Creek. We identified, measured, tagged with elastomer (if not previously tagged), and then returned all collected fish to their original pools. These 'monthly' pools were also part of a multi-year and multi-site study of the recruitment dynamics of intertidal sculpins (Ritter 2005). For each sampling date we determined whether individuals had been sampled on a previous occasion according to whether they had been previously tagged. Using a combination of their size and whether they were previously tagged, we identified which individuals had settled and recruited into the intertidal sculpin population by each sampling period ( $\leq 25 \mathrm{~mm}=$ 'new recruits'), as well as which individuals comprised the juvenile (26 to $35 \mathrm{~mm}$ ) and adult (>36 mm) size classes.

To determine whether recruitment levels, juvenile density and adult density differed between the 2 sites and across time in either 2002 or 2003, we analyzed the data from each size class and year combination separately using univariate repeated-measures ANOVAs. For the analysis of the 2003 data there were not enough degrees of freedom to run multivariate repeatedmeasures ANOVAs since there were more repeated measures than replicated units within treatments. Although it was possible to run multivariate repeatedmeasures ANOVAs on the 2002 data, we did not report the results of the multivariate analyses because they were in agreement with the results from all of the univariate analyses. Similar to the design of the daily settlement study, this study also incorporated a splitplot design (see description of analytical design in previous subsection 'Settlement surveys'). For each analysis, the data were $x^{0.5}$-transformed in order to meet the assumptions of the ANOVA. Based on observations of cross-correlations between sampling occasions, the 2002 data also met the assumption of sphericity for the univariate repeated-measures ANOVA; however, to be conservative we reported the Greenhouse-Geisser corrected p-values rather than the uncorrected p-values for the 2002 analysis (this assumption did not need to be met for the 2003 data because there were only 2 repeated sampling dates for 2003).

Tagging effects on growth and survival of recently settled sculpins. Previous studies of the effects of sub- cutaneous elastomer tags on the survivorship and growth of small reef fishes have produced varying results, indicating slight to no effect (Beukers et al. 1995, Frederick 1997, Malone et al. 1999). We therefore conducted 2 tagging studies in the laboratory to examine the effect of subcutaneous elastomer tags on the survivorship and growth of intertidal sculpins of settlement-recruitment size (13 to $25 \mathrm{~mm}$ ). For the first laboratory experiment, we evaluated the effect that tagging had on the survivorship and growth of sculpin recruits in the absence of predators. We collected 11 individuals of Clinocottus recalvus and 76 individuals of Oligocottus snyderi within the 13 to $25 \mathrm{~mm}$ size range from Pigeon Point, a site only a few kilometers north of Scott Creek. Recruits were evenly allocated among 4 different $10 \mathrm{gal}$ (40 l) aquaria according to a combination of their size, species and treatment (tagged with elastomer or untagged). We allocated 2 to 3 C. recalvus and 19 O. snyderi recruits of comparable sizes to each of the 4 aquaria, of which half were either tagged or untagged ( 1 to 2 C. recalvus and 9 to 10 $O$. snyderi). Throughout the experiment, we handled and treated all tagged and untagged individuals similarly. For the following $5 \mathrm{wk}$, we fed the fish and changed their water daily, and monitored the aquaria for mortality every 2 to $3 \mathrm{~d}$ for a total number of 11 repeated sampling dates. Repeated monitoring allowed us to compare both the trajectory of survivorship and the final number of survivors between the tagged and untagged treatments. Because there were no differences in the sizes of individuals between tagging treatments at the start of the experiment, we were able to determine whether growth varied depending upon tagging treatment by measuring the final sizes of all fishes surviving at the end of the $5 \mathrm{wk}$ experiment. Since there were very few individuals of C. globiceps and an uneven ratio of C. globiceps to O. snyderi, we pooled the data on both species for each of the subsequent analyses. To determine whether the tagging treatment affected the number of recruits surviving at the end of the experiment we conducted a univariate repeated-measures ANOVA (there were not sufficient degrees of freedom to run a multivariate repeatedmeasures ANOVA) with a randomized, complete block design, between-subjects component (Tagging treatment $=$ fixed factor, Aquarium = random factor) and the fixed, within-subjects factor Time. We analyzed the effects of Tagging on final size using a 2-factor ANOVA, with Tagging and Aquarium as fixed and random factors, respectively. We analyzed the raw (untransformed) data on survivorship and final size, since the data from this tagging study met the assumptions for both analyses.

In a second laboratory study, we examined the effects of the tagging procedure on the predation 
rates on recruits. We previously determined that adult Oligocottus snyderi would readily consume recruits of all 3 species in laboratory aquaria (Ritter 2005). Because individuals of $O$. snyderi are also the easiest to collect in large quantities, we used this species to represent both predators (adults) and prey (recruits) in these predation experiments. Our approach was to compare loss rates of tagged and untagged sculpin recruits exposed to predators. For each trial, we either placed 1 adult $O$. snyderi (>40 mm) into an aquarium along with 6 untagged $O$. snyderi recruits, or 1 adult into an aquarium along with 6 tagged recruits (all recruits were $<17 \mathrm{~mm} \mathrm{SL}$ ). We conducted 23 trials for this experiment, 13 with untagged recruits and 10 with tagged recruits. Each aquarium had constant fresh seawater flow, and all fish were fed daily throughout the experiment. We monitored the number of recruits remaining in the aquarium each day for the following $4 \mathrm{~d}$, and at the end of each trial we determined the average number of recruits consumed per day. We tested for differences in the average daily predation rate between tagged and untagged recruits using a single-factor ANOVA with tagging treatment as a fixed factor. We transformed the data with an $x^{0.25}$-transformation to meet the assumptions of the ANOVA.

\section{RESULTS}

\section{Spatial and temporal patterns in settlement}

The bi-daily and daily monitoring at Almar and Scott Creek indicated that settlement of all species com- bined was on average 4- to 5-fold greater at Scott Creek than at Almar (Fig. 2). Across both years of sampling, settlement levels per pool varied both among pools and from day to day, and overall settlement levels of all species combined were typically less than 1 ind. pool ${ }^{-1} \mathrm{~d}^{-1}$ (Fig. 2). Despite these low levels of settlement, we detected strong differences in overall rates of settlement (i.e. species combined) between sites for each year (Fig. 2, Table 2: Site). Settlement patterns were more temporally variable in 2002 than in 2003, as settlement declined over the sampling period in 2002 but not in 2003 (Fig. 2); this lead to a decrease in site differences and spatial species abundance differences over time within 2002 (Table 2: Time, Time $\times$ Site, and Time $\times$ Site $\times$ Species) .

There were strong differences in settlement rates between species each year (Fig. 3, Table 2: Species) and between sites (Fig. 3, Table 2: Site $\times$ Species). In 2002, settlement levels at Scott Creek were higher than at Almar for Clinocottus globiceps and for Oligocottus snyderi, but were fairly similar between the 2 sites for C. recalvus (Fig. 3a). In fact, although a few C. recalvus settlers were detected at Almar, even fewer C. globiceps and no $O$. snyderi settlers were detected at that site (Fig. 3a). In 2003, settlement levels at Scott Creek were again higher for all 3 species, but the difference between the 2 sites was again not as great for $C$. recalvus as it was for C. globiceps and O. snyderi (Fig. 3b, Table 2: Site $\times$ Species). Although a few $C$. recalvus settlers were detected at Almar in June 2003, no C. globiceps or $O$. snyderi settlers were detected during either low-tide series at that site. These species differences between sites were consistent over the 2003 sampling period (Table 2: Time $\times$ Site).
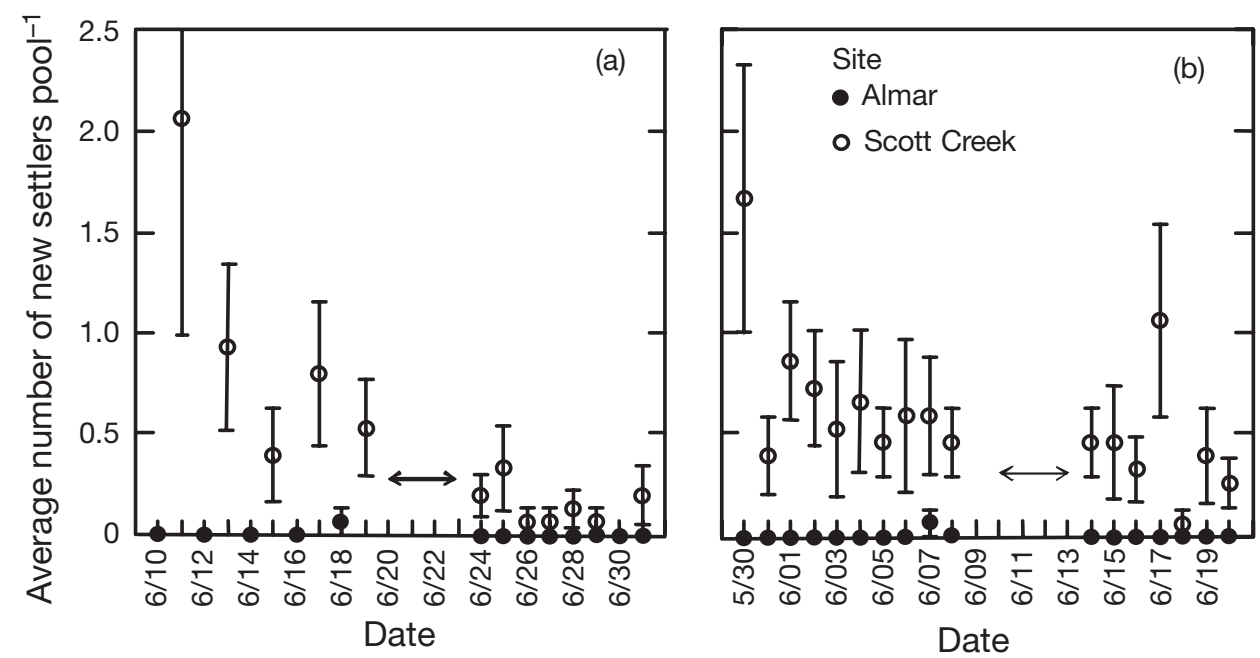

Fig. 2. Clinocottus globiceps, C. recalvus, and Oligocottus snyderi. Average number ( \pm SE from raw data) of new sculpin settlers (all species combined) pool ${ }^{-1} \mathrm{~d}^{-1}$ at Almar and at Scott Creek in (a) June 2002 and (b) June 2003 (dates presented as mo/d). Arrows $(\leftrightarrow)$ indicate neap low-tide periods when the tides were not sufficiently low to enable sampling of tidepools 
Table 2. Clinocottus globiceps, C. recalvus, and Oligocottus snyderi. Daily settlement surveys. Univariate repeated-measures ANOVA evaluating the effect of site, species, and time on the density $\left(x^{0.5}\right)$ of new sculpin settlers for 2 tide series each in June 2002 and June 2003. Within-plots p-values are Greenhouse-Geisser corrected

\begin{tabular}{|c|c|c|c|c|c|c|c|c|}
\hline \multirow{2}{*}{ Source } & \multicolumn{4}{|c|}{-2002} & \multicolumn{4}{|c|}{-2003} \\
\hline & df & MS & $F$ & $\mathrm{p}$ & df & MS & $F$ & $\mathrm{p}$ \\
\hline \multicolumn{9}{|l|}{ Between subjects } \\
\hline Site & 1,8 & 4.886 & 17.800 & 0.003 & 1,8 & 15.995 & 16.680 & 0.004 \\
\hline Pool (Site) & 8,16 & 0.275 & 0.988 & 0.480 & 8,16 & 0.959 & 2.922 & 0.032 \\
\hline \multicolumn{9}{|l|}{ Within subjects } \\
\hline Species & 2,16 & 1.900 & 6.838 & 0.007 & 2,16 & 6.484 & 19.756 & $<0.001$ \\
\hline Site $\times$ Species & 2,16 & 2.058 & 7.408 & 0.005 & 2,16 & 6.839 & 20.837 & $<0.001$ \\
\hline Residual & 16 & 0.278 & & & 16 & 0.328 & & \\
\hline \multicolumn{9}{|l|}{ Within sub-subjects } \\
\hline Time & 10,240 & 0.275 & 3.402 & 0.015 & 14,336 & 0.156 & 1.515 & 0.190 \\
\hline Time $\times$ Site & 10,240 & 0.242 & 3.004 & 0.027 & 14,336 & 0.150 & 1.452 & 0.211 \\
\hline Time $\times$ Species & 20,240 & 0.179 & 2.213 & 0.039 & 28,336 & 0.162 & 1.568 & 0.125 \\
\hline Time $\times$ Site $\times$ Species & 20,240 & 0.204 & 2.525 & 0.020 & 28,336 & 0.152 & 1.480 & 0.156 \\
\hline Residual & 240 & 0.081 & & & 336 & 0.103 & & \\
\hline
\end{tabular}

\section{Post-settlement survivorship and movement}

The absence of Clinocottus globiceps and Oligocottus snyderi settlers and the low number of C. recalvus settlers at Almar made it impossible to estimate the daily movement or survivorship rates of these species at Almar. At Scott Creek, only 2 species (C. globiceps and $O$. snyderi) had sufficiently high settlement levels to estimate daily survivorship and movement rates. Of originally captured and tagged settlers at Scott Creek, we recaptured 83 out of 120 O. snyderi and 8 out of 31 C. globiceps. The daily movement rates differed only slightly between the 2 species and indicated that recent $O$. snyderi settlers $\left(0.118\right.$ ind. $\mathrm{d}^{-1} \pm 0.047$ Wald $95 \%$ confidence interval) may have slightly greater post-settlement movement rates than C. globiceps $\left(0.071 \pm 0.103\right.$ ind $\left.\mathrm{d}^{-1}\right)$. Interestingly, the estimated daily survivorship rates for both these species at this site were very similar $-0.850 \pm 0.2358$ ind. $\mathrm{d}^{-1}$ and $0.9291 \pm 0.052$ ind. $\mathrm{d}^{-1}$ for C. globiceps and $O$. snyderi, respectively.

\section{Spatial and temporal patterns in assemblage and cohort structure}

Overall, patterns of recruitment and juvenile and adult densities of all 3 species estimated by the monthly surveys in both 2002 and 2003 reflected those described by the daily settlement surveys during the same period (Figs. 3 \& 4). In 2002, the relative rates of recruitment among the 3 species differed between the 2 sites: recruitment of Oligocottus snyderi was significantly higher at Scott Creek, recruitment of Clinocottus globiceps was slightly higher at Scott Creek, and recruitment of $C$. recalvus was slightly higher at Almar (Fig. 4a, Table 3: Site $\times$ Species term). Although there was temporal variation in recruitment rates (Table 3: Time), this temporal variation did not affect speciesspecific recruitment-abundance patterns across sites (Table 3: Time $\times$ Site $\times$ Species). The densities of juvenile C. globiceps and O. snyderi were greater at Scott Creek than at Almar, and the density of $C$. recalvus juveniles was greater at Almar (Fig. 4b, Table 3: Site $\times$ Species). However, the abundance patterns of juveniles were variable over time and may not have had the same species-specific spatial patterns for each sampling period (Table 3: Time $\times$ Site $\times$ Species) . Finally, patterns of adult density of all 3 species were largely consistent with those detected for both the recruits and the juveniles (Fig. 4c, Table 3). Species

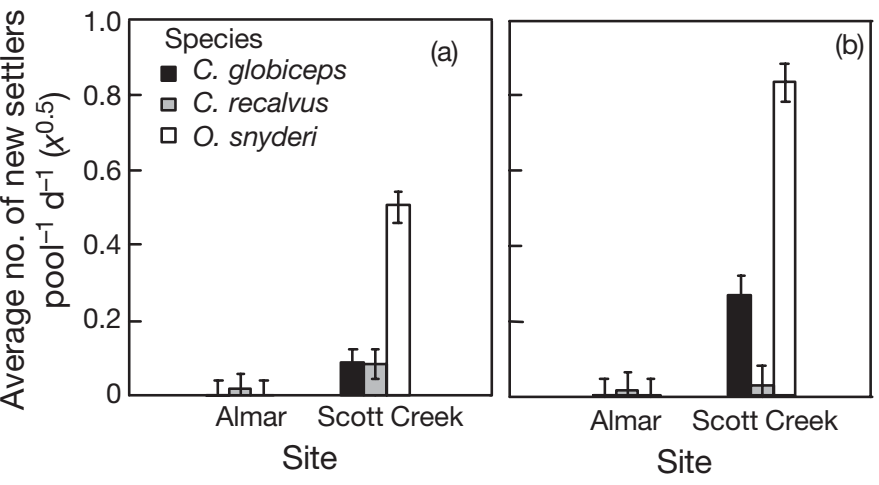

Fig. 3. Clinocottus globiceps, C. recalvus, and Oligocottus snyderi. Average number of new sculpin settlers pool ${ }^{-1} \mathrm{~d}^{-1}\left(x^{0.5} \pm \mathrm{SE}\right.$ from between-subject ANOVAs) of each of the 3 sculpin species at Almar and Scott Creek in (a) June 2002 and (b) June 2003 
Table 3. Clinocottus globiceps, C. recalvus, and Oligocottus snyderi. ANOVA testing effect of site and species on the density ( $x^{0.5}$ ) of 3 different size classes of tidepool sculpins in June, July, and August 2002 (within-subjects p-values are GreenhouseGeisser corrected)

\begin{tabular}{|c|c|c|c|c|c|c|c|c|c|c|}
\hline \multirow{2}{*}{ Source } & \multirow[b]{2}{*}{ df } & \multicolumn{3}{|c|}{ - Recruits } & \multicolumn{3}{|c|}{ - Juveniles } & \multirow[b]{2}{*}{ MS } & \multirow{2}{*}{$\begin{array}{c}\text { Adults } \\
\qquad F\end{array}$} & \multirow[b]{2}{*}{$\mathrm{p}$} \\
\hline & & MS & $F$ & $\mathrm{p}$ & MS & $F$ & $\mathrm{p}$ & & & \\
\hline \multicolumn{11}{|l|}{ Between subjects } \\
\hline Site & 1,8 & 13.544 & 7.025 & 0.029 & 34.154 & 16.858 & 0.003 & 30.530 & 6.856 & 0.031 \\
\hline Pool (Site) & 8,16 & 1.928 & 1.405 & 0.267 & 2.026 & 2.975 & 0.030 & 4.453 & 3.774 & 0.011 \\
\hline \multicolumn{11}{|l|}{ Within subjects } \\
\hline Species & 2,16 & 10.979 & 8.003 & 0.004 & 15.607 & 22.914 & 0.000 & 12.293 & 10.417 & 0.001 \\
\hline Site $\times$ Species & 2,16 & 20.767 & 15.137 & $<0.001$ & 29.669 & 43.561 & 0.000 & 15.596 & 13.216 & 0.000 \\
\hline Residual & 16 & 1.372 & & & 0.681 & & & 1.180 & & \\
\hline \multicolumn{11}{|l|}{ Within sub-subjects } \\
\hline Time & 2,48 & 3.509 & 7.861 & 0.002 & 2.198 & 7.378 & 0.002 & 0.867 & 3.204 & 0.059 \\
\hline Time $\times$ Site & 2,48 & 0.310 & 0.696 & 0.478 & 0.005 & 0.016 & 0.985 & 0.325 & 1.201 & 0.305 \\
\hline Time $\times$ Species & 4,48 & 0.134 & 0.301 & 0.842 & 0.391 & 1.314 & 0.278 & 0.699 & 2.584 & 0.061 \\
\hline Time $\times$ Site $\times$ Species & 4,48 & 1.009 & 2.260 & 0.091 & 1.355 & 4.551 & 0.003 & 0.184 & 0.680 & 0.585 \\
\hline Residual & 48 & 0.446 & & & 0.298 & & & 0.271 & & \\
\hline
\end{tabular}

Table 4. Clinocottus globiceps, C. recalvus, and Oligocottus snyderi. ANOVA testing effect of site and species on the density ( $x^{0.5}$ ) of 3 different size classes of tidepool sculpins in May and June 2003 (p-values not corrected since there were only 2 repeated measures)

\begin{tabular}{|c|c|c|c|c|c|c|c|c|c|c|}
\hline \multirow{2}{*}{ Source } & \multirow[b]{2}{*}{$\mathrm{df}$} & \multirow[b]{2}{*}{ MS } & \multirow{2}{*}{$\begin{array}{c}\text {-Recruits } \\
\text { F }\end{array}$} & \multirow[b]{2}{*}{$\mathrm{p}$} & \multicolumn{3}{|c|}{ Juveniles } & \multirow[b]{2}{*}{ MS } & \multirow{2}{*}{$\begin{array}{c}\text { - Adults } \\
F\end{array}$} & \multirow[b]{2}{*}{$\mathrm{p}$} \\
\hline & & & & & MS & $F$ & $\mathrm{p}$ & & & \\
\hline \multicolumn{11}{|l|}{ Between subjects } \\
\hline Site & 1,8 & 8.719 & 10.885 & 0.011 & 4.188 & 44.084 & $<0.001$ & 20.779 & 8.647 & 0.019 \\
\hline Pool (Site) & 8,16 & 0.801 & 1.185 & 0.366 & 0.095 & 0.402 & 0.903 & 2.403 & 4.715 & 0.004 \\
\hline \multicolumn{11}{|l|}{ Within subjects } \\
\hline Species & 2,16 & 5.524 & 8.166 & 0.004 & 2.555 & 10.787 & 0.001 & 4.350 & 8.538 & 0.003 \\
\hline Site $\times$ Species & 2,16 & 9.169 & 13.556 & 0.000 & 3.745 & 15.810 & 0.000 & 6.062 & 11.897 & 0.001 \\
\hline Residual & 16 & 0.676 & & & 0.237 & & & 0.510 & & \\
\hline \multicolumn{11}{|l|}{ Within subjects } \\
\hline Time & 2,24 & 0.103 & 0.532 & 0.473 & 1.798 & 13.786 & 0.001 & 0.153 & 0.890 & 0.355 \\
\hline Time $\times$ Site & 2,24 & 0.335 & 1.735 & 0.200 & 0.680 & 5.213 & 0.032 & 0.147 & 0.854 & 0.365 \\
\hline Time $\times$ Species & 4,24 & 0.204 & 1.060 & 0.362 & 0.590 & 4.525 & 0.022 & 0.202 & 1.172 & 0.327 \\
\hline Time $\times$ Site $\times$ Species & 4,24 & 0.088 & 0.458 & 0.638 & 1.149 & 8.811 & 0.011 & 0.876 & 5.089 & 0.014 \\
\hline Residual & 24 & 0.193 & & & 0.130 & & & 0.172 & & \\
\hline
\end{tabular}

Table 5. Clinocottus globiceps, C. recalvus, and Oligocottus snyderi. Univariate repeated-measures ANOVA testing effect of tagging treatment (elastomer-tagged or untagged) on number of fish surviving through time. Analytical design analysis included randomized, complete block between-subjects component (Tagging treatment fixed factor, Aquarium random factor) and fixed within-subjects factor (Time)

\begin{tabular}{|c|c|c|c|c|c|}
\hline Source & $\mathrm{df}$ & MS & Test & $F$ & $\mathrm{p}$ \\
\hline \multicolumn{6}{|l|}{ Between subjects } \\
\hline Tagging treatment (A) & 1,3 & 0.182 & $\mathrm{MS}_{\mathrm{A}} / \mathrm{MS}_{\mathrm{B}(\mathrm{A})}$ & 0.021 & 0.894 \\
\hline Aquarium (B[A]) & 3,3 & 8.818 & $\mathrm{MS}_{\mathrm{B}(\mathrm{A})} / \mathrm{MS}_{\text {residual }}$ & 1.014 & 0.496 \\
\hline Residual & 3 & 8.697 & & & \\
\hline \multicolumn{6}{|l|}{ Within subjects } \\
\hline Time $[\mathrm{C}]$ & 10,30 & 16.532 & $\mathrm{MS}_{\mathrm{C}} / \mathrm{MS}_{\mathrm{B}(\mathrm{A}) \times \mathrm{C}}$ & 20.613 & $<0.001$ \\
\hline Time $\times$ Tagging treatment $(\mathrm{C} \times \mathrm{A})$ & 10,30 & 0.532 & $\mathrm{MS}_{\mathrm{C} \times \mathrm{A}} / \mathrm{MS}_{\mathrm{B}(\mathrm{A}) \times \mathrm{C}}$ & 0.663 & 0.749 \\
\hline Time $\times$ Aquarium $(\mathrm{C} \times \mathrm{B}[\mathrm{A}])$ & 30,30 & 0.802 & $\mathrm{MS}_{\mathrm{B}(\mathrm{A}) \times \mathrm{C}} / \mathrm{MS}_{\text {residual }}$ & 1.937 & 0.038 \\
\hline Residual & 30 & 0.414 & & & \\
\hline
\end{tabular}


differed in their relative density between the 2 sites, with the density of C. globiceps and O. snyderi adults greater at Scott Creek, and the density of C. recalvus adults similar between the 2 sites (Table 3: Site $\times$ Species).

The largely consistent spatial patterns among settlement, recruitment, juveniles and adults detected in 2002 were detected again in 2003 (Fig. 4d,e,f). As in 2002, species differed in their relative recruitment between sites: Clinocottus globiceps and Oligocottus snyderi recruited in higher numbers at Scott Creek, whereas $C$. recalvus recruited in higher numbers at Almar (Fig. 4d, Table 4: Site $\times$ Species). Likewise, densities of juvenile C. globiceps and O. snyderi were on average greater at Scott Creek, and juvenile $C$. recalvus density was on average greater at Almar (Fig. 4e, Table 4: Site $\times$ Species), although the nature of these species-specific spatial patterns varied with time (Table 4: Time $\times$ Site $\times$ Species term). Although the spatial adult density patterns of each species varied with time (Table 4: Time $\times$ Site $\times$ Species), on average the density of adults of all 3 species was higher at Scott Creek and only $C$. recalvus adults were detected at Almar (Fig. 4f, Table 4: Site $\times$ Species).

\section{Effects of sampling procedure on mortality and growth}

In our laboratory experiment testing for effects of the tagging and sampling procedure on the mortality of recently settled sculpins, there were equivalent numbers of individuals in each aquarium at the beginning (tagged: $11.25 \pm 0.25$; untagged: $10.50 \pm 0.289$ ) and at the end (tagged: $7.25 \pm 0.479$; untagged: $7.00 \pm 0.913$ ) of the experiment. The results from the first tagging study indicate that the tagging treatment did not affect survivorship relative to the controls (Table 5: Tagging treatment). Survivorship trends were similar among tagging treatments (Table 5: Time $\times$ Tagging treatment), but differed somewhat among aquaria (Table 5: Time $\times$ Aquarium). We also did not detect an effect of tagging $\left(\mathrm{MS}_{\text {tagging treatment }}=2.710, F_{1,3}=0.258\right.$, $\mathrm{p}=0.646$; size of tagged fish $=23.741 \pm 0.752 \mathrm{~mm}$, size of untagged fish $=23.913 \pm 0.937 \mathrm{~mm}$ ) or aquarium $\left(\mathrm{MS}_{\text {aquarium }}=10.485, F_{3,42}=0.556, \mathrm{p}=0.647\right)$ on the overall growth of the fish, nor did we find that the growth of fish varied differentially with tagging treatment among aquaria $\left(\mathrm{MS}_{\text {tagging treatment } \times \text { aquarium }}=6.471\right.$, $\left.F_{3,42}=0.343, \mathrm{p}=0.794\right)$. The second laboratory study indicated that tagging treatment also had no effect on the rate of recruit predation by adults $\left(F_{1,21}=0.160\right.$, $\mathrm{p}=0.693, \mathrm{MS}_{\text {error }}=0.053$; number of tagged recruits consumed $\mathrm{d}^{-1}=1.990 \pm 0.684$, number of untagged recruits consumed $\mathrm{d}^{-1}=1.508 \pm 0.396$ ).

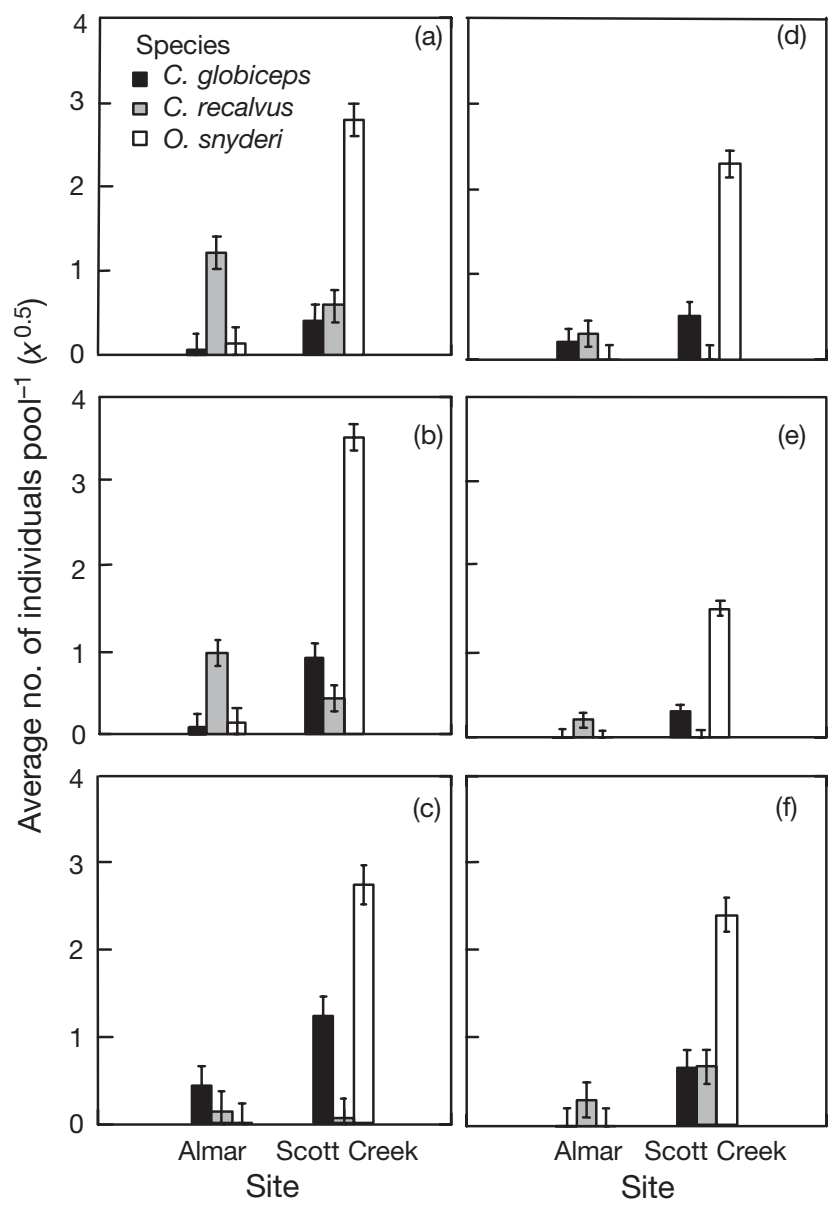

Fig. 4. Clinocottus globiceps, C. recalvus, and Oligocottus snyderi. Average number of sculpins $\mathrm{pool}^{-1}\left(x^{0.5} \pm\right.$ SE from between-subject ANOVAs) for all possible combinations of size class, species and year. (a,d) New recruits in 2002 and 2003, respectively; (b,e) juveniles in 2002 and 2003, respectively; $(\mathrm{c}, \mathrm{f})$ adults in 2002 and 2003, respectively

\section{DISCUSSION}

Spatial and temporal patterns of the structure and dynamics of marine populations are determined both by processes that drive variation in population replenishment and processes that alter or reinforce such variation over the subsequent juvenile and adult phases. The combined effects of variable larval production, dispersal, mortality, and settlement determine initial patterns of population replenishment, and studies of these processes continue to elucidate the ecology of marine populations (Menge 2000). Post-settlement processes, including species interactions (i.e. predation, competition, facilitation), disturbance and disease have received varying degrees of attention (Hughes 1994, Syms \& Jones 1999, Webster \& Hixon 2000). However, assessment of the relative contributions of variable replenishment (i.e. settlement) and post- 
settlement processes in determining spatial and temporal patterns of population structure and dynamics has received far less attention, particularly for temperate marine fishes. Only 2 studies have examined the spatial and temporal relationships between recruitment and later life stages of intertidal fishes, and our study is unique in having explored settlement, recruitment and patterns of older life stages of multiple species in the same assemblage at more than one site. This more comprehensive comparative approach detected spatial variation (between sites) in settlement and recruitment that was consistent over the $2 \mathrm{yr}$ of sampling. Moreover, these spatial patterns differed consistently among species and were consistent with the spatial patterns of juvenile and adult density of each species.

Although no other research has compared the importance of settlement versus post-settlement processes in structuring intertidal fish populations, other studies have explored the relationship between recruitment and demographic patterns of older life stages. Based on monthly surveys, one study found that recruitment pulses of tidepool sculpins in Washington State were maintained in the population for only a few months after their initial detection, suggesting that processes occurring during the juvenile phase greatly modified the original recruitment signal (Pfister 1996). In contrast, based on seasonal surveys, another study found that recruitment pulses of a tidepool sculpin in southern California were detectable throughout their subsequent life history stages, suggesting that processes occurring either before or during the recruitment phase were important in determining population structure (Davis \& Levin 2002). In this case, the manifestation of patterns of recruitment in later age classes suggests that the strength of density-dependent mortality was not sufficient to alter subsequent densities, or that spatial patterns of recruitment covaried with levels of limiting resources such as food or shelter (i.e. 'cryptic density-dependence' sensu Shima \& Osenberg 2003). The contrasting results of these 2 studies on intertidal fish recruitment highlight the importance of understanding not only how settlement and post-settlement processes affect the population structure of intertidal fishes, but also how these processes vary across space and time.

In this study, the settlement patterns of 3 tidepool sculpin species were consistent at each site over $2 \mathrm{yr}$. Throughout most post-settlement life history stages, Clinocottus recalvus was the most common species at one study site, whereas Oligocottus snyderi was the most common species at the second study site. Marine organisms with open population structure would not be expected to have such spatial and temporal consistency in their immediate post-settlement patterns, except when local larval delivery is driven by consistent variation in oceanographic processes or when populations are strongly regulated by localized postsettlement processes (Roughgarden et al. 1985, Caley et al. 1996). Although we were not able to assess larval delivery processes in this study, it was extremely pertinent that we further examined to what extent the patterns of settlement were modified by, independent of, or reinforced by post-settlement processes.

We found little evidence that early post-settlement processes were operating differentially across the intertidal fish populations in this study. Since we were unable to monitor the settlement of fishes when they were actually making the transition from larvae to settlers in the intertidal habitat, it is possible that we were unable to detect gross differences in immediate (i.e. less than $24 \mathrm{~h}$ ) post-settlement mortality. In addition, because the settlement levels of some of the species were very low, we were unable to actually estimate post-settlement survivorship for all the Species $\times$ Site combinations. Nevertheless, our estimates of early post-settlement survivorship provided little evidence for large differences in early post-settlement survivorship among at least 2 of the species at 1 of the study sites, despite the fact that one of these species represented high, and the other species low, settler densities at that site. Although post-settlement mortality does occur in these populations, it does not appear to be impacting the differences in settlement levels that we detected within a site among the different intertidal fish species. This is particularly interesting considering the contrasting densities of the 3 species across the 2 sites. Any post-settlement mortality occurring at these sites, except for within the first $24 \mathrm{~h}$ after settlement, is either cryptic or acting in a density-independent manner. Post-settlement processes can be very important in structuring marine fish abundances during the early benthic juvenile phase (Jones 1991, Carr 1994, Anderson 2001, Carr et al. 2002, Osenberg et al. 2002, Webster 2002, Forrester \& Steele 2004), and it is therefore surprising that there should be little difference in mortality among these intertidal species, particularly considering the differences in their settler densities at each of the study sites.

Another way in which to determine whether settlement or post-settlement processes are more important in structuring fish assemblages is to compare patterns of densities across different size classes or previous cohorts. Comparison of our daily settlement patterns with the monthly patterns of density of other size classes, reveals that the patterns between the 2 sites and among the 3 species are very similar across all size classes (Figs. $3 \& 4$ ). The one exception was Clinocottus recalvus, which initially demonstrated higher levels of settlement at Scott Creek than at Almar, but 
which was more abundant at Almar for all size classes other than settlers. This is in contrast to the other 2 species, which consistently had greater abundance at 1 of the 2 study sites for all size classes, and it suggests that $C$. recalvus may suffer relatively higher postsettlement mortality than the other 2 species at 1 of the 2 study sites. Nevertheless, despite this evidence for spatial variation in post-settlement mortality for one of the 3 intertidal fish species in this study, a general pattern still emerges: within a study site the relative settlement levels of each species is reflected in the relative abundance patterns of each species across different life history stages. This is particularly intriguing, since we are comparing settlement patterns to patterns established in previous cohorts that settled anywhere from months (recruits and juveniles) to 1 yr (adults) earlier, and we would not necessarily expect to find such close qualitative congruence. In addition, if we had only compared our estimate of monthly recruitment to the juvenile and adult density estimates, we would not have been able to determine whether settlement patterns or post-settlement processes occurring prior to recruitment were creating differences between sites and among species. Instead, since we found a close match among the patterns of daily settlement and the patterns established in previous cohorts, there is strong support for the idea that these patterns are largely driven by temporally consistent spatial variation in settlement processes.

Comparison between daily sampling of new settlers versus monthly sampling of new recruits also enables us to determine how differences in sampling frequency affect estimates of the input of new individuals into these intertidal fish populations. Since monitoring the arrival of new individuals on a daily basis is timeand labor-intensive, it is useful to know whether we are able to acquire the same type of information via monthly monitoring. Other studies have shown that variation in sampling frequency can significantly affect estimates of recruitment in both temperate intertidal barnacles (Minchinton \& Scheibling 1993) and tropical coral reef fishes (Booth 1991). Estimates of settlement may not accurately reflect the actual numbers of settlers transitioning from the larval to the benthic phase in real time, so it is important that we monitored intertidal sculpin settlement at the highest frequency possible. Our results suggest that sampling on a daily or a monthly basis will give qualitatively similar estimates of the relative number of new individuals of each species arriving at the intertidal sculpin populations at the 2 focal sites in this study.

Overall settlement levels were quite low in these intertidal sculpin species compared with levels in other studies of temperate reef fish settlement patterns (Carr 1994, Levin 1994, Steele 1997, Hartney \& Grorud
2002), despite the fact that we conducted the settlement surveys at the time of year when recruitment levels peak in these species (Pfister 1996, Ritter 2005). It is likely that daily settlement rates in these species are quite low not only because densities of residents per pool are consistently low, but also because females produce (at most) a few small benthic clutches of eggs $\left(\sim 100\right.$ to 200 eggs clutch $\left.{ }^{-1}\right) \mathrm{yr}^{-1}$, and because they have a protracted (6 mo long) settlement season (Grossman $\&$ Devlaming 1984). In addition, the patterns of settlement that we detected are likely to be reflective of the differences in larval availability between the 2 sites. Even though Almar and Scott Creek are very similar in habitat characteristics, and the pools that we monitored were very similar, Almar is overall a much smaller intertidal habitat with respect to area than Scott Creek is. In addition, within the northern Monterey Bay region where Almar is located, there are very few other intertidal habitats where sculpin populations could be supported. Consequently, if larval supply levels between the 2 sites were similar, we would either expect to see higher densities of settlers per pool at Almar than at Scott Creek, or significantly greater mortality of settlers at Almar than at Scott Creek. Neither our estimates of post-settlement survivorship among species nor our estimates of the settlement levels among species at the 2 sites support this idea. Rather, our results suggest that the differences in species-specific settlement levels between the 2 sites indicate differences in larval availability.

In conclusion, settlement processes were more important than post-settlement processes in determining the population and assemblage structure of the intertidal fish populations examined in this study. The combined examination of site- and species-specific patterns in settlement levels, post-settlement survivorship, and the density of other size classes in this study suggests that the populations of intertidal fishes at these sites are either recruitment-limited (sensu Doherty 1981), or that their densities are so low that no density-dependent processes strongly modify the original settlement patterns (Holm 1990). Another possibility that may explain why the patterns are so consistent across different cohorts is that these populations of intertidal sculpins are not as open as would be predicted for marine organisms with a dispersive larval stage. In particular, if dispersal distance of these sculpins is limited such that rates of larval supply and settlement are determined by local rates of larval production, supply and settlement rates may reflect production rates that are density-dependent (i.e. resource-limited). Indeed, the temporal consistency among years and cohorts suggests that patterns of larval production may reflect some spatially consistent limiting resource. The debate over whether popula- 
tions of marine organisms are more often structured by larval supply (i.e. recruitment limitation) or settlement and post-settlement processes (i.e. mortality) specifically refers to those types of marine organisms that have truly open populations (Caley et al. 1996). If, however, there is more retention of larvae within local populations than would be predicted by the open population theory, it is possible to detect a coupling between patterns in different cohorts that reflects patterns of larval production rather than the outcome of settlement or post-settlement processes. Several recent studies have shown that marine organisms with dispersive larvae may still have significant retention of locally produced offspring (Jones et al. 1999, Swearer et al. 1999, 2002, Cowen 2002). The approximate 3 to 4 wk larval period of intertidal sculpins (Blizard 2000) is short relative to that of many other temperate reef fishes (Carr \& Syms in press). Moreover, 2 studies have found that intertidal sculpin larvae exhibit behaviors that may enable them to stay very close to shore (Marliave 1986, Feeney 1992). If sculpin larvae do have the ability to stay close to the intertidal zone, then it is possible that the concordance between settlement patterns and the densities of prior cohorts is due to the fact that the link between local reproduction and local replenishment in intertidal sculpins is stronger than their larval duration and open population theory would predict.

Acknowledgements. We thank A. Zacher and M. Marquez for excellent assistance in the field, as well as M. Carr, P. Raimondi, C. Syms, and D. Doak for comments on this manuscript. We thank A. Chaine and T. Preisler for continuous encouragement and support. This work was supported by the Project for the Interdisciplinary Studies of the Coastal Oceans (PISCO) funded by the David and Lucile Packard Foundation, funding to A.F.R. from the University of California Office of the President, the Center for Dynamics of the Land Sea Interface at the University of California Santa Cruz (UCSC), Myers Oceanographic Trust, and from the Friends of Long Marine Laboratory (UCSC). This is contribution No. 197 from PISCO.

\section{LITERATURE CITED}

Ambrose DA (1996) The early stages of fishes in the California Current region. Calif Coop Ocean Fish Investig Rep 33:821-833

Anderson TW (2001) Predator responses, prey refuges, and density-dependent mortality of a marine fish. Ecology 82: 245-257

Beukers JS, Jones GP, Buckley RM (1995) Use of implant microtags for studies on populations of small reef fish. Mar Ecol Prog Ser 125:61-66

Blizard R (2000) Life histories and otolith microstructure variation of intertidal sculpins. Masters thesis, San Francisco State University, San Francisco, CA

Booth DJ (1991) The effects of sampling frequency on estimates of recruitment of the domino damselfish Dascyllus albisella Gill. J Exp Mar Biol Ecol 145:149-160
Breitburg DL (1991) Settlement patterns and presettlement behavior of the naked goby, Gobiosoma bosci, a temperate oyster reef fish. Mar Biol 109:213-221

Caffey HM (1985) Spatial and temporal variation in settlement and recruitment of intertidal barnacles. Ecol Monogr 55:313-332

Caley MJ, Carr MH, Hixon MA, Hughes TP, Jones GP, Menge BA (1996) Recruitment and the local dynamics of open marine populations. Annu Rev Ecol Syst 27:477-500

Carr MH (1994) Effects of macroalgal dynamics on recruitment of a temperate reef fish. Ecology 75:1320-1333

Carr MH, Syms C (in press) Chapter 15: Recruitment. In: Allen LG, Pondella DJI, Horn MH (eds) The ecology of California marine fishes. University of California Press, Berkeley, CA

Carr MH, Anderson TW, Hixon MA (2002) Biodiversity, population regulation, and the stability of coral-reef fish communities. Proc Natl Acad Sci USA 99:11241-11245

Caselle JE (1999) Early post-settlement mortality in a coral reef fish and its effect on local population size. Ecol Monogr 69:177-194

Caswell H (1978) Predator-mediated coexistence: a nonequilibrium model. Am Nat 112:127-154

Connell JH (1985) The consequences of variation in initial settlement vs. post-settlement mortality in rocky intertidal communities. J Exp Mar Biol Ecol 93:11-45

Cowen RK (2002) Larval dispersal and retention and consequences for population connectivity. In: Sale PF (ed) Coral reef fishes: dynamics and diversity in a complex ecosystem. Academic Press, San Diego, CA, p 149-170

Davis JLD, Levin LA (2002) Importance of pre-recruitment life-history stages to population dynamics of the woolly sculpin Clinocottus analis. Mar Ecol Prog Ser 234:229-246

DeMartini ED (1999) Intertidal spawning. In: Horn MH, Martin KL, Chotkowski MA (eds) Intertidal fishes. Academic Press, San Diego, CA, p 143-164

Doherty P (1981) Coral reef fishes: recruitment-limited assemblages? Proc 4th Int Coral Reef Symp 2:465-470

Doherty PJ, Fowler A (1994) Demographic consequences of variable recruitment to coral reef fish populations: a congeneric comparison of two damselfishes. Bull Mar Sci 54: 297-313

Doherty PJ, Williams DM (1988) The replenishment of coral reef fish populations. Oceanogr Mar Biol Annu Rev 26: $487-551$

Feeney RF (1992) Post-yolk sac larval development of two southern California sculpins, Clinocottus analis and Orthonopias triacis (Pisces: Cottidae). Calif Dep Fish Game Fish Bull 90:454-468

Forrester GE (1995) Strong density-dependent survival and recruitment regulate the abundance of a coral reef fish. Oecologia 103:275-282

Forrester GE, Steele MA (2004) Predators, prey refuges, and the spatial scaling of density-dependent prey mortality. Ecology 85:1332-1342

Frederick JL (1997) Evaluation of fluorescent elastomer injection as a method for marking small fish. Bull Mar Sci 61: 399-408

Gaines S, Roughgarden J (1985) Larval settlement rate: a leading determinant of structure in an ecological community of the marine intertidal zone. Proc Natl Acad Sci USA 82:3707-3711

Gaines S, Brown S, Roughgarden J (1985) Spatial variation in larval concentrations as a cause of spatial variation in settlement for the barnacle Balanus glandula. Oecologia 67:267-272

Grossman GD, Devlaming V (1984) Reproductive ecology of 
female Oligocottus snyderi: a North American intertidal sculpin. J Fish Biol 25:231-240

Harley C, Helmuth BS (2003) Local- and regional-scale effects of wave exposure, thermal stress, and absolute versus effective shore level on patterns of intertidal zonation. Limnol Oceanogr 48:1498-1508

Hartney KB, Grorud KA (2002) The effect of sea urchins as biogenic structures on the local abundance of a temperate reef fish. Oecologia 131:506-513

Hixon MA, Carr MH (1997) Synergistic predation, density dependence, and population regulation in marine fish, Science 277:946-949

Holm ER (1990) Effects of density-dependent mortality on the relationship between recruitment and larval settlement. Mar Ecol Prog Ser 60:141-146

Hubbs C (1966) Fertilization, initiation of cleavage, and developmental temperature tolerance of the cottid fish, Clinocottus analis. Copeia 1966:29-42

Hughes TP (1994) Catastrophes, phase shifts, and large-scale degradation of a Caribbean coral reef. Science 265: $1547-1551$

Jones GP (1991) Postrecruitment processes in the ecology of coral reef fish populations: a multifactorial perspective. In: Sale PF (ed) The ecology of fishes on coral reefs. Academic Press, San Diego, CA, p 294-328

Jones GP, Milicich MJ, Emslie MJ, Lunow C (1999) Selfrecruitment in a coral reef fish population. Nature 402: 802-804

Keough MJ, Downes BJ (1982) Recruitment of marine invertebrates: the role of active choices and early mortality. Oecologia 54:348-352

Kinlan BP, Gaines SD (2003) Propagule dispersal in marine and terrestrial environments: a community perspective. Ecology 84:2007-2020

Levin PS (1994) Fine-scale temporal variation in recruitment of a temperate demersal fish-the importance of settlement versus postsettlement loss. Oecologia 97: 124-133

Malone JC, Forrester GE, Steele MA (1999) Effects of subcutaneous microtags on the growth, survival, and vulnerability to predation of small reef fishes. J Exp Mar Biol Ecol 237:243-253

Marliave JB (1986) Lack of planktonic dispersal of rocky intertidal fish larvae. Trans Am Fish Soc 115:149-154

Martin KL (1993) Aerial release of $\mathrm{CO}_{2}$ and respiratory exchange ratio in intertidal fishes out of water. Environ Biol Fish 37:189-196

Menge BA (2000) Recruitment vs. postrecruitment processes as determinants of barnacle population abundance. Ecol Monogr 70:265-288

Milicich MJ, Meekan MG, Doherty PJ (1992) Larval supply: a good predictor of recruitment of 3 species of reef fish (Pomacentridae). Mar Ecol Prog Ser 86:153-166

Miller D, Lea RN (1972) Guide to the coastal marine fishes of California, Vol 157. California Department of Fish and Game, Oakland, CA

Minchinton TE, Scheibling RE (1993) Variations in sampling procedure and frequency affect estimates of recruitment of barnacles. Mar Ecol Prog Ser 99:83-88

Nakamura R (1976) Temperature and the vertical distribution of two tidepool fishes (Oligocottus maculosus, O. snyderi). Copeia 1976:143-152

Osenberg CW, St. Mary CM, Schmitt RJ, Holbrook SJ, Chesson P, Byrne B (2002) Rethinking ecological inference: density dependence in reef fishes. Ecol Lett 5: $715-721$
Pfister CA (1996) The role and importance of recruitment variability to a guild of tidepool fishes. Ecology 77 : 1928-1941

Pfister CA (1997) Demographic consequences of within-year variation in recruitment. Mar Ecol Prog Ser 153:229-238

Quinn GP, Keough MJ (2002) Experimental design and data analysis for biologists. Cambridge University Press, Cambridge

Raimondi PT (1990) Patterns, mechanisms, consequences of variability in settlement and recruitment of an intertidal barnacle. Ecol Monogr 60:283-310

Ritter AF (2005) The influence of processes at different scales on the population dynamics of intertidal fishes. $\mathrm{PhD}$ dissertation, University of California, Santa Cruz, CA

Roughgarden J, Iwasa Y, Baxter C (1985) Demographic theory for an open marine population with space-limited recruitment. Ecology 66:54-67

Sale PF (1980) The ecology of fishes on coral reefs. Oceanogr Mar Biol Annu Rev 18:367-421

Sale PF (1991) The ecology of fishes on coral reefs. Academic Press, San Diego, CA

Schmitt RJ, Holbrook SJ (1999) Settlement and recruitment of three damselfish species: larval delivery and competition for shelter space. Oecologia 118:76-86

Shanks AL, Grantham BA, Carr MH (2003) Propagule dispersal distance and the size and spacing of marine reserves. Ecol Appl 13:S159-S169

Shima JS, Osenberg CW (2003) Cryptic density dependence: effects of covariation between density and site quality in reef fish. Ecology 84:46-52

Steele MA (1997) Population regulation by post-settlement mortality in two temperate reef fishes. Oecologia 112: 64-74

Swearer SE, Caselle JE, Lea DW, Warner RR (1999) Larval retention and recruitment in an island population of a coral reef fish. Nature 402:799-802

Swearer SE, Shima JS, Helberg ME, Thorrold SR and 6 others (2002) Evidence of self-recruitment in demersal marine populations. Bull Mar Sci 70:251-271

Syms C, Jones GP (1999) Scale of disturbance and the structure of a temperate fish guild. Ecology 80:921-940

Tupper M, Boutilier RG (1995) Effects of conspecific density on settlement, growth and post-settlement survival of a temperate reef fish. J Exp Mar Biol Ecol 191:209-222

Underwood AJ, Denley EJ (1984) Paradigms explanations and generalizations in models for the structure of intertidal communities on rocky shores. In: Strong DR, Simberloff D, Abele LG, Thistle AB (eds) Ecological communities: conceptual issues and the evidence. Princeton University Press, Princeton, NJ, p 151-180

Washington B, Moser H, Laroch W, Richards W (1984) Scorpaeniformes: development. Spec Publ Am Soc Ichthyol Herpetol 1:405-428

Webster MS (2002) Role of predators in the early post-settlement demography of coral-reef fishes. Oecologia 131: 52-60

Webster MS, Hixon MA (2000) Mechanisms and individual consequences of intraspecific competition in a coral-reef fish. Mar Ecol Prog Ser 196:187-194

Wilson J, Osenberg CW (2002) Experimental and observational patterns of density-dependent settlement and survival in the marine fish Gobiosoma. Oecologia 130: $205-215$

Yoshiyama RM, Sassaman C, Lea RN (1986) Rocky intertidal fish communities of California: temporal and spatial variation. Environ Biol Fish 17:23-40

Submitted: February 17, 2005; Accepted: November 10, 2005 Proofs received from author(s): June 22, 2006 